\title{
Use of the Oxazole-Olefin Diels-Alder Reaction in the Total Synthesis of the Monoterpene Alkaloids (-)-Plectrodorine and (+)-Oxerine
}

\author{
Masashi Oнва, ${ }^{*, a}$ Rie Izuta, ${ }^{b}$ and Emi Shimizu ${ }^{b}$ \\ ${ }^{a}$ Advanced Science Research Center, Kanazawa University; and ${ }^{b}$ Faculty of Pharmaceutical Sciences, Kanazawa \\ University; Kakuma-machi, Kanazawa 920-1192, Japan. Received July 21, 2005; accepted September 20, 2005
}

\begin{abstract}
A full account of the total synthesis of two monoterpene alkaloids, (-)-plectrodorine [(-)-1] and (+)oxerine [(+)-3], is presented. The key steps involved are the formation of the oxazole alcohol 10 from the $\gamma$-butyrolactone 9 and the intramolecular Diels-Alder reaction of the oxazole-olefins $13 \mathrm{a}, \mathrm{b}$. Since the sign of specific rotation for the synthetic $(+)-3$ was different from that reported for natural oxerine, the absolute configuration of this alkaloid is not yet fully understood.
\end{abstract}

Key words oxazole-olefin; Diels-Alder reaction; cyclopenta[c]pyridine; monoterpene alkaloid; plectrodorine; oxerine

Oxazoles have been shown to behave as dependable azadiene components in Diels-Alder reactions. ${ }^{1)}$ Since Kondrat'eva reported the first example of a Diels-Alder reaction of an oxazole with an olefin to produce a pyridine in $1957,,^{2,3)}$ this methodology has become a valuable tool for the preparation of highly substituted pyridines, such as pyridoxine and its analogues. Despite an early recognition of the practical value of the oxazole-olefin Diels-Alder reaction, there are few reports applying this cycloaddition intramolecularly to the synthesis of pyridine-containing natural products. ${ }^{4-19)}$ In the present study, we sought to explore the feasibility of intramolecular oxazole-olefin Diels-Alder reaction for an efficient construction of two monoterpene alkaloids possessing the cyclopenta $[c]$ pyridine ring system. ${ }^{20-23)}$

Plectrodorine (1), selected as the first target for the monoterpene alkaloids, was isolated as a racemate together with isoplectrodorine (2) from the aerial parts of Plectronia odorata (Rubiaceae) by Koch and co-workers. ${ }^{24)}$ The structure and relative stereochemistry of $\mathbf{1}$ were elucidated through a combination of spectral analysis and chemical transformation. The Koch group ${ }^{25)}$ then described the isolation of oxerine from the aerial parts of Oxera morieri (Verbenaceae) and proposed its absolute stereochemistry to be $(5 R, 7 S)-\mathbf{3}$ by partial synthesis of oxerine from harpagide of known absolute configuration. ${ }^{26)}$ We chose $(5 R, 7 S)-3$ as the second target to demonstrate the versatility of our synthetic strategy, although racemic synthesis of oxerine has been accomplished by several research groups. ${ }^{27-30)} \mathrm{A}$ brief account of the results reported here has been published in a preliminary form. ${ }^{31)}$

For the construction of the cyclopenta[c]pyridine skeleton via the intramolecular Diels-Alder reaction of oxazoles, we planned to employ the oxazole-olefin 4 . The introduction of suitable olefinic dienophiles to the oxazole aldehyde $\mathbf{5}$ would provide 4 , whereas the oxazole ring of 5 was envisaged to arise from the addition of $\alpha$-lithiated methyl isocyanide to

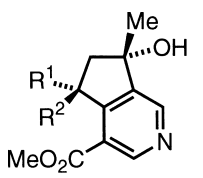

1: $\mathrm{R}^{1}=\mathrm{OH}, \mathrm{R}^{2}=\mathrm{H}$

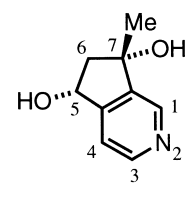

2: $\mathrm{R}^{1}=\mathrm{H}, \mathrm{R}^{2}=\mathrm{OH}$ the $\gamma$-butyrolactone $\mathbf{6}$ according to the procedure of Jacobi. ${ }^{32,33)}$

The requisite $\gamma$-butyrolactone 6 was readily obtained from Seebach's dioxolanone 7.34,35) Thus, reduction of 7 with $\mathrm{BH}_{3} \cdot \mathrm{Me}_{2} \mathrm{~S}$ followed by alkaline hydrolysis and acid-promoted lactone formation afforded $\mathbf{6}$ in $73 \%$ yield. The absolute configuration of $\mathbf{6}$ was further substantiated by the identity of specific rotation of the benzoate $\mathbf{8}$, derived from $\mathbf{6}$, with the data reported in the literature. ${ }^{36)}$ After protection of the tertiary hydroxy group in $\mathbf{6}$ with tert-butyldimethylsilyl triflate (TBDMSOTf) to afford the lactone $\mathbf{9}$, the formation of an oxazole ring was carried out by treatment of 9 with 2.5 eq of $\alpha$-lithiated methyl isocyanide in THF at $-78^{\circ} \mathrm{C}$ for $3 \mathrm{~h}$ followed by addition of $\mathrm{AcOH}$, a slight modification of the Jacobi method, ${ }^{32,33)}$ giving the alcohol $\mathbf{1 0}$ in $66 \%$ yield. With a view to introducing an olefinic dienophile, the alcohol $\mathbf{1 0}$ was converted into the aldehyde $\mathbf{1 1}$ in $85 \%$ yield by means of the Swern oxidation. ${ }^{37)}$

Coupling reaction of the aldehyde $\mathbf{1 1}$ and methyl trans-3iodoacrylate ${ }^{38)}$ with $\mathrm{CrCl}_{2}$ and a catalytic amount of $\mathrm{NiCl}_{2}$ in $\mathrm{DMSO}^{39-41)}$ was first performed directed toward the synthesis of plectrodorine (1), furnishing the allylic alcohol 12a as a 2:1 diastereoisomeric mixture in $61 \%$ yield. The oxazole-olefin 13a desired for the intramolecular Diels-Alder reaction was then obtained in $89 \%$ yield by oxidation of 12a with the Dess-Martin periodinane. ${ }^{42-44)}$ When a $0.05 \mathrm{~m}$ solution of 13a in $o$-dichlorobenzene $(o$-DCB) was heated at $150{ }^{\circ} \mathrm{C}$ for $48 \mathrm{~h}$, the bicyclic pyridine 14a was obtained in $37 \%$ yield, together with recovered 13a (23\%). On treatment

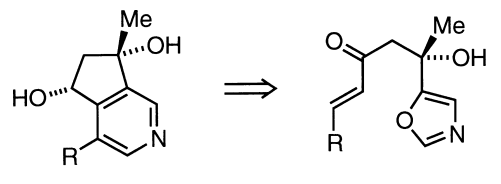

1: $\mathrm{R}=\mathrm{CO}_{2} \mathrm{Me}$ 4 3: $\mathrm{R}=\mathrm{H}$

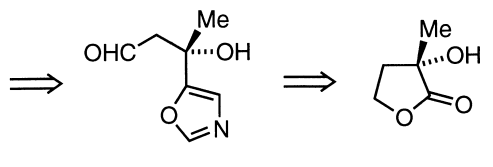

5 Chart 1 


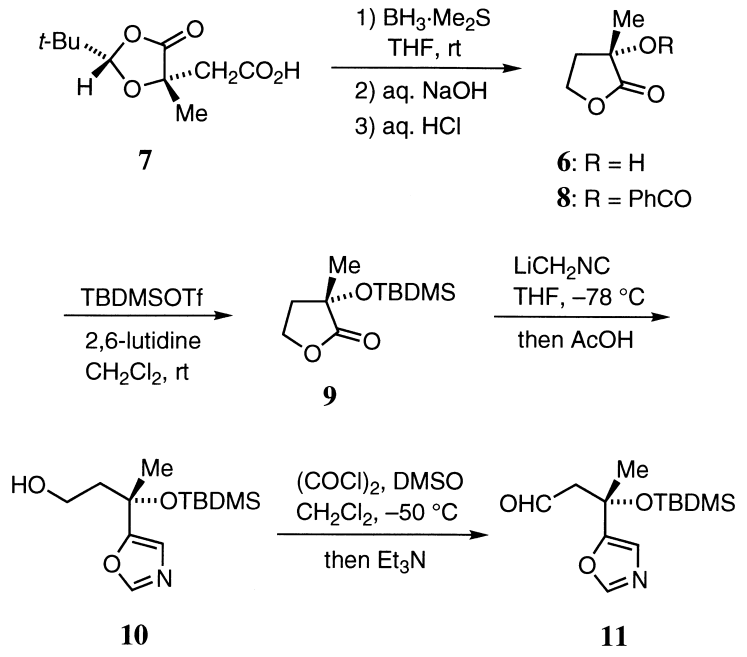

Chart 2

of the solution at the higher temperature $\left(180^{\circ} \mathrm{C}\right)$ for $24 \mathrm{~h}$, both the yield of 14a and the recovery of 13a decreased to $19 \%$ and $10 \%$, respectively. The carbonyl group of $\mathbf{1 4 a}$ was reduced with $\mathrm{NaBH}_{4}$ in $\mathrm{MeOH}$ at $0{ }^{\circ} \mathrm{C}$ to generate the alcohol 15a (75\% yield), whose stereochemistry was determined on the basis of $7 \%$ NOE enhancements of $\mathrm{C}(6)-\mathrm{H} \beta$ signal observed on separate irradiations of $\mathrm{C}(5)-\mathrm{H}$ and $\mathrm{C}(7)-\mathrm{Me}$ signals, together with its $\mathrm{C}(5)$-epimer ( $10 \%$ yield). The high stereoselectivity in reduction of 14a is probably due to access of the hydride from an orientation avoiding the bulky tertbutyldimethylsilyloxy group at the 7-position. Finally, deprotection of 15a with tetrabutylammonium fluoride gave the first target (-)-1 in $73 \%$ yield. The synthetic $(-)-\mathbf{1}$ proved to be virtually identical with natural plectrodorine ${ }^{24)}$ by a direct comparison of the UV, ${ }^{1} \mathrm{H}-\mathrm{NMR}$, and mass spectra.

We next turned our attention to the synthesis of oxerine (3). On treatment with vinylmagnesium bromide in THF at $-10^{\circ} \mathrm{C}$, the aldehyde 11 was converted into a $1: 1$ diastereoisomeric mixture of the allylic alcohol 12b $(82 \%$ yield), which was then oxidized with the Dess-Martin periodinane to provide the oxazole-olefin $\mathbf{1 3 b}$ in $93 \%$ yield. The intramolecular Diels-Alder reaction of $\mathbf{1 3 b}$ was carried out by heating its $0.05 \mathrm{M} o-\mathrm{DCB}$ solution at $150^{\circ} \mathrm{C}$, affording the desired pyridine $14 \mathrm{~b}$ as a sole isolable product in $23 \%$ yield with the complete disappearance of $\mathbf{1 3 b}$ after $9 \mathrm{~h}$. A parallel result was also obtained by the reaction of $13 \mathbf{b}$ at $180^{\circ} \mathrm{C}$. The observed low yield of $\mathbf{1 4 b}$ is presumably due to the decomposition of the terminal olefin 13b at elevated temperature. Although we have recently reported that the conversion of the oxazole-olefin 16 into the bicyclic pyridine $\mathbf{1 7}$ was promoted by addition of a catalytic amount of $\mathrm{Cu}(\mathrm{OTf})_{2},{ }^{45}$ the catalyst was not effective for $\mathbf{1 3 b}$. Thus, treatment of 13b in the presence of $\mathrm{Cu}(\mathrm{OTf})_{2}(2 \mathrm{~mol} \%)$ in $o$-DCB at $180^{\circ} \mathrm{C}$ for $40 \mathrm{~min}$ proceeded with accompanying deprotection followed by elimination of $\mathrm{H}_{2} \mathrm{O}$, furnishing the olefin $\mathbf{1 8}^{46}$ ) in $38 \%$ yield. Reduction of $\mathbf{1 4 b}$ with $\mathrm{NaBH}_{4}$ in $\mathrm{EtOH}$ at $0{ }^{\circ} \mathrm{C}$ provided the alcohol $\mathbf{1 5 b}$ as a sole isomer in $84 \%$ yield. Again, the stereochemistry of $\mathbf{1 5 b}$ was ascertained by the NOE experiments. The second target $(+)-3\left[[\alpha]_{D}^{23}+10.6^{\circ}\right.$ $(c=0.21, \mathrm{MeOH})]$ was obtained in $91 \%$ yield via deprotection of $\mathbf{1 5 b}$ with tetrabutylammonium fluoride. Although the $\mathrm{UV},{ }^{1} \mathrm{H}-\mathrm{NMR}$, and mass spectra of the synthetic (+)-3 were
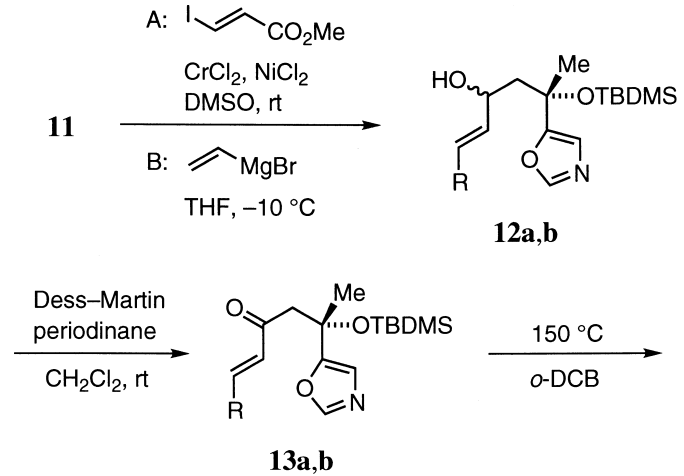

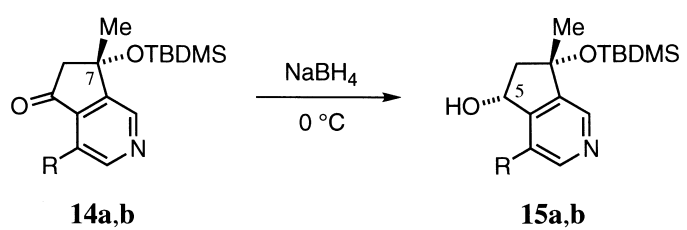<smiles>[R]c1cncc2c1[C@@H](O)C[C@]2(C)O</smiles>

Chart 3

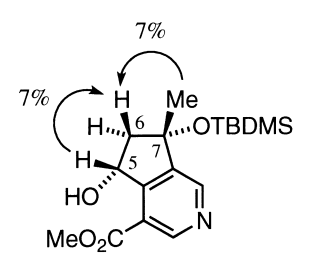

$15 \mathbf{a}$

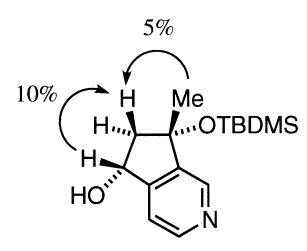

$15 b$
Fig. 1. NOE Data of the Alcohols 15a, b

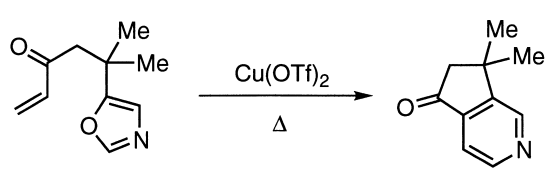

16<smiles>C=CC(=O)CC(C)(O[AsH3])c1cnco1</smiles>

$13 b$
17

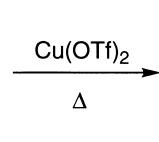<smiles>C=CC(=O)C=C(C)c1cnco1</smiles>

18
Chart 4

found to match those of natural oxerine $\left[[\alpha]_{\mathrm{D}}^{20}-11^{\circ}\right.$ $(c=0.20, \mathrm{MeOH})],{ }^{25)}$ the signs of specific rotation for the two samples were opposite. Unfortunately, we were unable to draw a chiroptical comparison between ( +$)-3$ and oxerine on account of paucity of the natural sample. The circular dichroism (CD) spectrum and specific rotation $\left[[\alpha]_{\mathrm{D}}^{24}+8.0^{\circ}\right.$ $(c=0.15, \mathrm{MeOH})]$ of a sample newly derived from harpagide by Koch as well as its ${ }^{1} \mathrm{H}-\mathrm{NMR}$ spectrum were identical with those of (+)-3. However, because of an incomplete identifi- 
cation of oxerine and the sample prepared from harpagide, the absolute configuration of oxerine remains undefined until this alkaloid is further isolated from natural sources.

In conclusion, the total synthesis of $(-)$-plectrodorine $[(-)-1]$ and $(+)$-oxerine $[(+)-3]$ possessing the cyclopenta$[c]$ pyridine ring system has been accomplished in eight steps, respectively, from the $\gamma$-butyrolactone $\mathbf{6}$. It also exemplifies the usefulness of the intramolecular oxazole-olefin DielsAlder reaction for the synthesis of annulated pyridine-containing natural products.

\section{Experimental}

General Notes All melting points were determined on a Yamato MP-1 capillary melting point apparatus. Flash chromatography ${ }^{47)}$ was carried out using Merck silica gel 60 (No. 9385). The organic solutions obtained after extraction were dried over anhydrous $\mathrm{MgSO}_{4}$ and concentrated under reduced pressure. The ratios of solvents in mixtures are shown in $\mathrm{v} / \mathrm{v}$. Spectra reported herein were recorded on a JEOL JMS-SX102A mass spectrometer, a Hitachi 330 UV spectrophotometer, a Shimadzu IR-460 or a Shimadzu FTIR-8100 IR spectrophotometer, a JASCO J-725 spectropolarimeter, or a JEOL JNM-GSX-500 $\left({ }^{1} \mathrm{H} 500 \mathrm{MHz}\right)$ NMR spectrometer. Chemical shifts are reported in ppm downfield from internal $\mathrm{Me}_{4} \mathrm{Si}$. Optical rotations were measured with a Horiba SEPA-300 polarimeter using a 1-dm sample tube. The following abbreviations are used: $\mathrm{br}=$ broad, $\mathrm{d}=$ doublet, $\mathrm{dd}=$ doubletof-doublets, ddd= doublet-of-dd's, $\mathrm{m}=$ multiplet, $\mathrm{s}=$ singlet, $\mathrm{sh}=$ shoulder.

(3S)-Dihydro-3-hydroxy-3-methyl-2(3H)-furanone (6) A stirred solution of $7(326 \mathrm{mg}, 1.5 \mathrm{mmol})$ in THF $(8 \mathrm{ml})$ was cooled to $0{ }^{\circ} \mathrm{C}$, and a $2.0 \mathrm{M}$ solution $(1.8 \mathrm{ml}, 3.6 \mathrm{mmol})$ of $\mathrm{BH}_{3} \cdot \mathrm{Me}_{2} \mathrm{~S}$ in THF was added dropwise over $15 \mathrm{~min}$. After stirring at room temperature for $28 \mathrm{~h}, \mathrm{H}_{2} \mathrm{O}(3 \mathrm{ml})$ and $\mathrm{K}_{2} \mathrm{CO}_{3}$ $(360 \mathrm{mg})$ were added successively under cooling. The mixture was then extracted with ether and the ethereal extracts were washed with saturated aqueous $\mathrm{NaCl}$, dried, and concentrated. The resulting yellow oil was dissolved in EtOH $(6 \mathrm{ml})$ and cooled to $0{ }^{\circ} \mathrm{C}$. After addition of $2 \mathrm{~N}$ aqueous $\mathrm{NaOH}(3 \mathrm{ml})$, the solution was stirred at room temperature for $30 \mathrm{~min}$, concentrated in vacuo by half, acidified with $10 \%$ aqueous $\mathrm{HCl}$, and continuously extracted with ether for $10 \mathrm{~h}$. The ethereal extracts were dried and concentrated to leave a pale yellow oil, which was purified by flash chromatography [hexane-AcOEt $(1: 1)]$ to yield $6(128 \mathrm{mg}, 73 \%)$ as a colorless oil, $[\alpha]_{\mathrm{D}}^{23}$ $-36.3^{\circ}\left(c=0.51, \mathrm{CHCl}_{3}\right)$; IR $v_{\max }^{\text {film }} \mathrm{cm}^{-1}: 3410(\mathrm{OH}), 1768$ (lactone $\left.\mathrm{CO}\right) ;{ }^{1} \mathrm{H}-$ NMR $\left(\mathrm{CDCl}_{3}\right) \delta: 1.51(3 \mathrm{H}, \mathrm{s}, \mathrm{Me}), 2.26(1 \mathrm{H}, \mathrm{ddd}, J=13,7,4.5 \mathrm{~Hz})$ and 2.44 $(1 \mathrm{H}$, ddd, $J=13,8,8 \mathrm{~Hz})\left[\mathrm{C}(4) \mathrm{H}_{2}\right], 2.66(1 \mathrm{H}, \mathrm{s}, \mathrm{OH}), 4.23(1 \mathrm{H}$, ddd, $J=9.5$, $8,7 \mathrm{~Hz})$ and $4.42(1 \mathrm{H}$, ddd, $J=9.5,8,4.5 \mathrm{~Hz})\left[\mathrm{C}(5) \mathrm{H}_{2}\right]$; HR-EI-MS $\mathrm{m} / \mathrm{z}$ Calcd for $\mathrm{C}_{5} \mathrm{H}_{8} \mathrm{O}_{3}: 116.0473$, Found: 116.0470 .

(3S)-3-(Benzoyloxy)dihydro-3-methyl-2(3H)-furanone (8) A mixture of $6(70 \mathrm{mg}, 0.6 \mathrm{mmol}), \mathrm{Et}_{3} \mathrm{~N}(121 \mathrm{mg}, 1.2 \mathrm{mmol})$, and 4-(dimethylamino)pyridine $(10 \mathrm{mg}, 0.08 \mathrm{mmol})$ in $\mathrm{CH}_{2} \mathrm{Cl}_{2}(3 \mathrm{ml})$ was stirred at $0{ }^{\circ} \mathrm{C}$, and a solution of benzoyl chloride $(127 \mathrm{mg}, 0.9 \mathrm{mmol})$ in $\mathrm{CH}_{2} \mathrm{Cl}_{2}(1 \mathrm{ml})$ was added. After having been stirred at room temperature for $16 \mathrm{~h}$, the reaction mixture was washed successively with saturated aqueous $\mathrm{NaHCO}_{3}$ and saturated aqueous $\mathrm{NaCl}$, dried, and concentrated. Purification of the residual solid by flash chromatography [hexane-AcOEt $(2: 1)$ ] provided $8(127 \mathrm{mg}$, $96 \%)$ as a colorless solid, which was recrystallized from AcOEt-hexane $(2: 1)$ to afford colorless plates, $\mathrm{mp} 144-146^{\circ} \mathrm{C} ;[\alpha]_{\mathrm{D}}^{23}-16.3^{\circ}(c=0.91$, $\mathrm{CHCl}_{3}$ ). The melting point, specific rotation, and ${ }^{1} \mathrm{H}-\mathrm{NMR}$ spectral data for this sample were in agreement with those reported in the literature. ${ }^{36)}$

(3S)-3-[[(1,1-Dimethylethyl)dimethylsilyl] oxy]dihydro-3-methyl2(3H)-furanone (9) A solution of $6(741 \mathrm{mg}, 6.4 \mathrm{mmol})$ in $\mathrm{CH}_{2} \mathrm{Cl}_{2}(20 \mathrm{ml})$ was stirred at $0{ }^{\circ} \mathrm{C}$, and TBDMSOTf $(3.7 \mathrm{ml}, 16.1 \mathrm{mmol})$ and 2,6-lutidine $(2.6 \mathrm{ml}, 22.3 \mathrm{mmol})$ were added in that order. After having been stirred at room temperature for $2 \mathrm{~h}$, the reaction mixture was washed with saturated aqueous $\mathrm{NaCl}$, dried, and concentrated to leave a pale orange oil. Purification by flash chromatography [hexane-AcOEt $(10: 1)$ ] gave $9(1.46 \mathrm{~g}, 99 \%)$ as a colorless solid, $\mathrm{mp} 29.5-31^{\circ} \mathrm{C} ;[\alpha]_{\mathrm{D}}^{24}+12.9^{\circ}\left(c=0.51, \mathrm{CHCl}_{3}\right)$; CI-MS $m / z: 231\left(\mathrm{M}+\mathrm{H}^{+}\right)$; IR $v_{\max }^{\text {Nujol }}: 1771 \mathrm{~cm}^{-1}$ (lactone CO); ${ }^{1} \mathrm{H}-\mathrm{NMR}\left(\mathrm{CDCl}_{3}\right) \delta$ : 0.12 and 0.18 ( $3 \mathrm{H}$ each, s, $\left.\mathrm{SiMe}_{2}\right), 0.87(9 \mathrm{H}, \mathrm{s}$, tert-Bu), $1.48(3 \mathrm{H}, \mathrm{s}, \mathrm{CMe})$, $2.16(1 \mathrm{H}$, ddd, $J=13,7,7 \mathrm{~Hz})$ and $2.32(1 \mathrm{H}$, ddd, $J=13,7,5 \mathrm{~Hz})\left[\mathrm{C}(4) \mathrm{H}_{2}\right]$, $4.21(1 \mathrm{H}$, ddd, $J=9,7,5 \mathrm{~Hz})$ and $4.35(1 \mathrm{H}, \mathrm{ddd}, J=9,7,7 \mathrm{~Hz})\left[\mathrm{C}(5) \mathrm{H}_{2}\right]$ HR-FAB-MS $m / z$ Calcd for $\mathrm{C}_{11} \mathrm{H}_{23} \mathrm{O}_{3} \mathrm{Si}$ : 231.1416, Found: 231.1418 .

$(\gamma S)-\gamma$-[I(1,1-Dimethylethyl)dimethylsilyl]oxy]- $\gamma$-methyl-5-oxazolepropanol (10) A solution of methyl isocyanide $(246 \mathrm{mg}, 6.0 \mathrm{mmol})$ in THF $(12 \mathrm{ml})$ was stirred at $-78^{\circ} \mathrm{C}$ in an atmosphere of $\mathrm{N}_{2}$, and a $1.5 \mathrm{M}$ solu- tion $(4.0 \mathrm{ml}, 6.0 \mathrm{mmol})$ of BuLi in hexane was added dropwise over $15 \mathrm{~min}$. After the mixture had been stirred for $15 \mathrm{~min}$, a solution of $9(560 \mathrm{mg}$, $2.4 \mathrm{mmol})$ in THF $(5 \mathrm{ml})$ was introduced dropwise over $10 \mathrm{~min}$. Stirring was then continued for a further $3 \mathrm{~h}$, and the reaction was quenched by adding $\mathrm{AcOH}(6.0 \mathrm{ml})$. The mixture was brought to room temperature and concentrated under reduced pressure. The residue was partitioned between $\mathrm{H}_{2} \mathrm{O}$ and ether, and the ethereal extracts were washed with saturated aqueous $\mathrm{NaCl}$, dried, and concentrated. Purification of the residual oil by flash chromatography [AcOEt-hexane $(1: 1)]$ gave $\mathbf{1 0}(438 \mathrm{mg}, 66 \%)$ as a colorless oil, $[\alpha]_{\mathrm{D}}^{24}$ $-27.4^{\circ}\left(c=0.51, \mathrm{CHCl}_{3}\right)$; CI-MS $m / z: 272\left(\mathrm{M}+\mathrm{H}^{+}\right)$; IR $v_{\max }^{\text {film: }}: 3370 \mathrm{~cm}^{-1}$ $(\mathrm{OH}) ;{ }^{1} \mathrm{H}-\mathrm{NMR}\left(\mathrm{CDCl}_{3}\right) \delta$ : -0.11 and $0.04\left(3 \mathrm{H} \mathrm{each}, \mathrm{s}, \mathrm{SiMe}_{2}\right), 0.89(9 \mathrm{H}$, $\mathrm{s}$, tert-Bu), $1.68(3 \mathrm{H}, \mathrm{s}, \mathrm{CMe}), 1.98(1 \mathrm{H}, \mathrm{ddd}, J=14,6.5,5.5 \mathrm{~Hz})$ and 2.20 $(1 \mathrm{H}$, ddd $J=14,7,6 \mathrm{~Hz})\left[\mathrm{C}(\beta) \mathrm{H}_{2}\right], 2.37(1 \mathrm{H}, \mathrm{br}, \mathrm{OH}), 3.77[2 \mathrm{H}, \mathrm{m}$, $\mathrm{C}(\alpha) \mathrm{H}_{2}$ ], 6.94 [1H, s, C(4)H], 7.83 [1H, s, C(2)H]; HR-FAB-MS $m / z$ Calcd for $\mathrm{C}_{13} \mathrm{H}_{26} \mathrm{NO}_{3} \mathrm{Si}: 272.1682$, Found: 272.1687 .

$(\beta S)-\beta$-[[(1,1-Dimethylethyl)dimethylsilyl]oxy]- $\beta$-methyl-5-oxazolepropanal (11) A solution of oxalyl chloride $(0.37 \mathrm{ml}, 4.2 \mathrm{mmol})$ in $\mathrm{CH}_{2} \mathrm{Cl}_{2}(12 \mathrm{ml})$ was cooled to $-60^{\circ} \mathrm{C}$ in an atmosphere of $\mathrm{N}_{2}$, and a solution of DMSO $(0.60 \mathrm{ml}, 8.5 \mathrm{mmol})$ in $\mathrm{CH}_{2} \mathrm{Cl}_{2}(2 \mathrm{ml})$ was added. After the mixture had been stirred for $5 \mathrm{~min}$, a solution of $\mathbf{1 0}(562 \mathrm{mg}, 2.1 \mathrm{mmol})$ in $\mathrm{CH}_{2} \mathrm{Cl}_{2}(4 \mathrm{ml})$ was added dropwise over $2 \mathrm{~min}$. Stirring was then continued at $-60{ }^{\circ} \mathrm{C}$ for a further $30 \mathrm{~min}$. The reaction mixture, after addition of $\mathrm{Et}_{3} \mathrm{~N}$ $(2.4 \mathrm{ml})$, was brought to room temperature and partitioned between $\mathrm{CH}_{2} \mathrm{Cl}_{2}$ and $\mathrm{H}_{2} \mathrm{O}$. The $\mathrm{CH}_{2} \mathrm{Cl}_{2}$ extracts were washed with saturated aqueous $\mathrm{NaCl}$, dried, and concentrated to leave a yellow oil. Purification by flash chromatography [hexane-AcOEt $(2: 1)$ ] furnished $11(474 \mathrm{mg}, 85 \%)$ as a slightly yellow oil, $[\alpha]_{\mathrm{D}}^{24}-44.1^{\circ}\left(c=0.51, \mathrm{CHCl}_{3}\right)$; FAB-MS $m / z: 270$ (M+ $\left.\mathrm{H}^{+}\right)$; IR $v_{\max }^{\text {film }}: 1725 \mathrm{~cm}^{-1}(\mathrm{CHO}) ;{ }^{1} \mathrm{H}-\mathrm{NMR}\left(\mathrm{CDCl}_{3}\right) \delta:-0.12$ and $0.04(3 \mathrm{H}$ each, s, $\left.\mathrm{SiMe}_{2}\right), 0.87(9 \mathrm{H}, \mathrm{s}$, tert-Bu), $1.73(3 \mathrm{H}, \mathrm{s}, \mathrm{CMe}), 2.70$ and $2.89[1 \mathrm{H}$ each, dd, $\left.J=15.5,3 \mathrm{~Hz}, \mathrm{C}(\alpha) \mathrm{H}_{2}\right], 6.98[1 \mathrm{H}, \mathrm{s}, \mathrm{C}(4) \mathrm{H}], 7.85[1 \mathrm{H}, \mathrm{s}, \mathrm{C}(2) \mathrm{H}]$, $9.86(1 \mathrm{H}, \mathrm{dd}, J=3,3 \mathrm{~Hz}, \mathrm{CHO})$; HR-FAB-MS $m / z$ Calcd for $\mathrm{C}_{13} \mathrm{H}_{24} \mathrm{NO}_{3} \mathrm{Si}$ : 270.1526, Found: 270.1525 .

$(2 E, 6 S)-6-[[(1,1-D i m e t h y l e t h y l)$ dimethylsilyl]oxy]-4-hydroxy-6-(5-oxazolyl)-2-heptenoic Acid Methyl Ester (12a) A solution of $11(472 \mathrm{mg}$, $1.75 \mathrm{mmol}$ ) and methyl trans-3-iodoacrylate ${ }^{38)}(1.12 \mathrm{~g}, 5.3 \mathrm{mmol})$ in DMSO $(25 \mathrm{ml})$ was stirred in an atmosphere of $\mathrm{Ar}$, and $\mathrm{CrCl}_{2}(1.29 \mathrm{~g}, 10.5 \mathrm{mmol})$ containing $\mathrm{NiCl}_{2}(2.3 \mathrm{mg}, 0.018 \mathrm{mmol})$ was added in portions. The resulting dark green mixture was then stirred at room temperature for $72 \mathrm{~h}$. The reaction mixture was quenched by addition of saturated aqueous $\mathrm{NH}_{4} \mathrm{Cl}(10 \mathrm{ml})$ under cooling and extracted with ether. The combined ethereal extracts were washed with saturated aqueous $\mathrm{NaCl}$, dried, and concentrated. Purification of the residual oil by flash chromatography [hexane-AcOEt $(1: 1)]$ provided 12a (381 mg, $61 \%)$ as a slightly yellow oil, $[\alpha]_{\mathrm{D}}^{24}-22.6^{\circ}\left(c=0.57, \mathrm{CHCl}_{3}\right)$; FAB-MS $m / z$ : $356\left(\mathrm{M}+\mathrm{H}^{+}\right)$; IR $v_{\max }^{\text {film }} \mathrm{cm}^{-1}: 3410(\mathrm{OH}), 1725$ (ester CO); ${ }^{1} \mathrm{H}-\mathrm{NMR}\left(\mathrm{CDCl}_{3}\right) \delta:-0.18(1 \mathrm{H}),-0.03(2 \mathrm{H}), 0.04(1 \mathrm{H})$, and $0.12(2 \mathrm{H})(\mathrm{s}$ each, $\left.\mathrm{SiMe}_{2}\right), 0.89(3 \mathrm{H})$ and $0.93(6 \mathrm{H})(\mathrm{s}$ each, tert- $\mathrm{Bu}), 1.72(2 \mathrm{H})$ and 1.78 $(1 \mathrm{H})$ (s each, CMe), $1.80(1 / 3 \mathrm{H}, \mathrm{dd}, J=14.5,2 \mathrm{~Hz}), 1.95(2 / 3 \mathrm{H}, \mathrm{dd}, J=14.5$, $9.5 \mathrm{~Hz}), 2.01(2 / 3 \mathrm{H}$, dd, $J=14.5,2.5 \mathrm{~Hz})$, and $2.25(1 / 3 \mathrm{H}, \mathrm{dd}, J=14.5$, $10.5 \mathrm{~Hz})\left[\mathrm{C}(5) \mathrm{H}_{2}\right], 3.72(2 \mathrm{H})$ and $3.73(1 \mathrm{H})\left(\mathrm{s}\right.$ each, $\left.\mathrm{CO}_{2} \mathrm{Me}\right), 3.85(2 / 3 \mathrm{H})$ and $3.88(1 / 3 \mathrm{H})(\mathrm{br}$ each, $\mathrm{OH}), 4.48(2 / 3 \mathrm{H})$ and $4.71(1 / 3 \mathrm{H})(\mathrm{m}$ each, $\mathrm{CHOH}), 6.09(2 / 3 \mathrm{H})$ and $6.14(1 / 3 \mathrm{H})$ [dd each, $J=15.5,2 \mathrm{~Hz}, \mathrm{C}(2) \mathrm{H}], 6.81$ $(2 / 3 \mathrm{H}, \mathrm{dd}, J=15.5,4.5 \mathrm{~Hz})$ and $6.87(1 / 3 \mathrm{H}, \mathrm{dd}, J=15.5,4 \mathrm{~Hz})[\mathrm{C}(3) \mathrm{H}], 6.97$ $(1 / 3 \mathrm{H})$ and $6.99(2 / 3 \mathrm{H})$ [s each, $\left.\mathrm{C}\left(4^{\prime}\right) \mathrm{H}\right], 7.85\left[1 \mathrm{H}, \mathrm{s}, \mathrm{C}\left(2^{\prime}\right) \mathrm{H}\right]{ }^{48)} \mathrm{HR}-\mathrm{FAB}-$ MS $m / z$ Calcd for $\mathrm{C}_{17} \mathrm{H}_{30} \mathrm{NO}_{5} \mathrm{Si}: 356.1893$, Found: 356.1902 .

$(\gamma S)$ - $\gamma$-[I(1,1-Dimethylethyl)dimethylsilyl]oxy]- $\alpha$-ethenyl- $\gamma$-methyl-5oxazolepropanol (12b) A mixture of THF $(5 \mathrm{ml})$ and a $0.95 \mathrm{M}$ solution $(1.7 \mathrm{ml}, 1.6 \mathrm{mmol})$ of vinylmagnesium bromide in THF was cooled to $-10^{\circ} \mathrm{C}$ in an atmosphere of $\mathrm{N}_{2}$, and a solution of $11(308 \mathrm{mg}, 1.1 \mathrm{mmol})$ in THF $(2 \mathrm{ml})$ was added dropwise over $5 \mathrm{~min}$. After the mixture had been stirred at $-10{ }^{\circ} \mathrm{C}$ for $30 \mathrm{~min}$, the reaction was quenched by adding saturated aqueous $\mathrm{NH}_{4} \mathrm{Cl}(3 \mathrm{ml})$. The whole was extracted with ether, and the ethereal extracts were washed with saturated aqueous $\mathrm{NaCl}$, dried, and concentrated to leave a pale yellow oil. Purification by flash chromatography [hexaneAcOEt $(5: 2)]$ gave $\mathbf{1 2 b}(280 \mathrm{mg}, 82 \%)$ as a colorless oil, $[\alpha]_{\mathrm{D}}^{23}-26.7^{\circ}$ $\left(c=0.49, \mathrm{CHCl}_{3}\right)$; FAB-MS m/z: $298\left(\mathrm{M}+\mathrm{H}^{+}\right)$; IR $v_{\max }^{\text {film }}: 3380 \mathrm{~cm}^{-1}(\mathrm{OH})$; ${ }^{1} \mathrm{H}-\mathrm{NMR}\left(\mathrm{CDCl}_{3}\right) \delta:-0.19,-0.04,0.03$, and $0.11\left(3 / 2 \mathrm{H}\right.$ each, s, $\left.\mathrm{SiMe}_{2}\right)$, 0.88 and $0.93(9 / 2 \mathrm{H}$ each, $\mathrm{s}$, tert $-\mathrm{Bu}), 1.71$ and 1.77 (3/2H each, s, CMe), $1.74(1 / 2 \mathrm{H}, \mathrm{dd}, J=14.5,2 \mathrm{~Hz}), 1.94(1 / 2 \mathrm{H}, \mathrm{dd}, J=14.5,3 \mathrm{~Hz}), 1.99(1 / 2 \mathrm{H}$, dd, $J=14.5,9 \mathrm{~Hz})$, and $2.27(1 / 2 \mathrm{H}$, dd, $J=14.5,10.5 \mathrm{~Hz})\left[\mathrm{C}(\beta) \mathrm{H}_{2}\right], 3.48$ and 3.62 (1/2H each, br s, OH), 4.30 and 4.51 (1/2H each, br m, CHOH), 5.04 and $5.08\left(1 / 2 \mathrm{H}\right.$ each, ddd, $\left.J=10.5,1.5,1.5 \mathrm{~Hz}, \mathrm{CH}=\mathrm{CH}_{2}\right), 5.20$ and 5.28 $\left(1 / 2 \mathrm{H}\right.$ each, ddd, $\left.J=17.5,1.5,1.5 \mathrm{~Hz}, \mathrm{CH}=\mathrm{CH}_{2}\right), 5.77$ and $5.83(1 / 2 \mathrm{H}$ each, ddd, $\left.J=17.5,10.5,6 \mathrm{~Hz}, \mathrm{C} \underline{\mathrm{H}}=\mathrm{CH}_{2}\right), 6.96$ and $6.97[1 / 2 \mathrm{H}$ each, $\mathrm{s}, \mathrm{C}(4) \mathrm{H}]$, 
7.84 and $7.85[1 / 2 \mathrm{H}$ each, s, C(2)H]; HR-FAB-MS $\mathrm{m} / \mathrm{z}$ Calcd for $\mathrm{C}_{15} \mathrm{H}_{28} \mathrm{NO}_{3} \mathrm{Si}: 298.1838$, Found: 298.1842 .

(2E,6S)-6-[[(1,1-Dimethylethyl)dimethylsilyl] $] 0 x y]-6-(5-0 x a z o l y l)-4-$ oxo-2-heptenoic Acid Methyl Ester (13a) A solution of 12a $(341 \mathrm{mg}$, $0.96 \mathrm{mmol})$ in $\mathrm{CH}_{2} \mathrm{Cl}_{2}(3 \mathrm{ml})$ was added to a stirred solution of the DessMartin periodinane ${ }^{42-}{ }^{44)}(610 \mathrm{mg}, 1.4 \mathrm{mmol})$ in $\mathrm{CH}_{2} \mathrm{Cl}_{2}(10 \mathrm{ml})$. After having been stirred at room temperature for $45 \mathrm{~min}$, the reaction mixture was poured into saturated aqueous $\mathrm{NaHCO}_{3}(10 \mathrm{ml})$ containing $\mathrm{Na}_{2} \mathrm{~S}_{2} \mathrm{O}_{3}(1.8 \mathrm{~g})$. The biphasic mixture was stirred for $5 \mathrm{~min}$ and extracted with ether. The organic phases were combined, washed successively with saturated aqueous $\mathrm{NaHCO}_{3}$ and saturated aqueous $\mathrm{NaCl}$, dried, and concentrated to leave a yellow oil, which was purified by flash chromatography [hexane-AcOEt $(2: 1)]$ to afford 13a $(301 \mathrm{mg}, 89 \%)$ as a pale yellow oil, $[\alpha]_{\mathrm{D}}^{23}-90.7^{\circ}(c=0.50$, $\mathrm{CHCl}_{3}$ ); FAB-MS $m / z: 354\left(\mathrm{M}+\mathrm{H}^{+}\right)$; IR $v_{\max }^{\text {film }} \mathrm{cm}^{-1}: 1731$ (ester CO), 1690 (CO); ${ }^{1} \mathrm{H}-\mathrm{NMR}\left(\mathrm{CDCl}_{3}\right) \delta:-0.16$ and -0.03 (3H each, s, $\left.\mathrm{SiMe}_{2}\right), 0.84(9 \mathrm{H}$, s, tert-Bu), $1.73(3 \mathrm{H}, \mathrm{s}, \mathrm{CMe}), 2.95$ and 3.26 [1H each, d, $J=14 \mathrm{~Hz}, \mathrm{C}(5) \mathrm{H}_{2}$ ], $3.80\left(3 \mathrm{H}, \mathrm{s}, \mathrm{CO}_{2} \mathrm{Me}\right), 6.62$ and $7.11[1 \mathrm{H}$ each, d, $J=16 \mathrm{~Hz}, \mathrm{C}(2) \mathrm{H}, \mathrm{C}(3) \mathrm{H}]$, $6.94\left[1 \mathrm{H}, \mathrm{s}, \mathrm{C}\left(4^{\prime}\right) \mathrm{H}\right], 7.83\left[1 \mathrm{H}, \mathrm{s}, \mathrm{C}\left(2^{\prime}\right) \mathrm{H}\right] ;^{48)} \mathrm{HR}-\mathrm{FAB}-\mathrm{MS} m / z$ Calcd for $\mathrm{C}_{17} \mathrm{H}_{28} \mathrm{NO}_{5} \mathrm{Si}: 354.1737$, Found: 354.1743 .

(5S)-5-[[(1,1-Dimethylethyl)dimethylsilyl]oxy]-5-(5-oxazolyl)-1-hexen3-one (13b) A mixture of 12b $(563 \mathrm{mg}, 1.9 \mathrm{mmol})$ and the Dess-Martin periodinane ${ }^{42-44)}(1.23 \mathrm{~g}, 2.9 \mathrm{mmol})$ in $\mathrm{CH}_{2} \mathrm{Cl}_{2}(23 \mathrm{ml})$ was stirred at room temperature for $80 \mathrm{~min}$. The reaction mixture was worked up as described above for 13a. Purification of a crude oil by flash chromatography [hexane-AcOEt $(5: 2)$ ] furnished $\mathbf{1 3 b}(521 \mathrm{mg}, 93 \%)$ as a colorless oil, $[\alpha]_{\mathrm{D}}^{23}-70.8^{\circ}\left(c=0.49, \mathrm{CHCl}_{3}\right)$; FAB-MS $m / z: 296\left(\mathrm{M}+\mathrm{H}^{+}\right)$; IR $v_{\max }^{\text {film: }}$ $1694 \mathrm{~cm}^{-1}(\mathrm{CO}) ;{ }^{1} \mathrm{H}-\mathrm{NMR}\left(\mathrm{CDCl}_{3}\right) \delta:-0.16$ and -0.02 (3H each, $\mathrm{s}$, $\left.\mathrm{SiMe}_{2}\right), 0.84(9 \mathrm{H}, \mathrm{s}$, tert-Bu $), 1.74(3 \mathrm{H}, \mathrm{s}, \mathrm{CMe}), 2.98$ and 3.19 [1H each, d, $\left.J=14 \mathrm{~Hz}, \mathrm{C}(4) \mathrm{H}_{2}\right], 5.75(1 \mathrm{H}, \mathrm{dd}, J=10.5,1 \mathrm{~Hz})$ and $6.18(1 \mathrm{H}, \mathrm{dd}, J=17.5$, $1 \mathrm{~Hz})\left[\mathrm{C}(1) \mathrm{H}_{2}\right], 6.34[1 \mathrm{H}, \mathrm{dd}, J=17.5,10.5 \mathrm{~Hz}, \mathrm{C}(2) \mathrm{H}], 6.93\left[1 \mathrm{H}, \mathrm{s}, \mathrm{C}\left(4^{\prime}\right)-\right.$ $\mathrm{H}], 7.82\left[1 \mathrm{H}, \mathrm{s}, \mathrm{C}\left(2^{\prime}\right) \mathrm{H}\right] ;{ }^{48)}$ HR-FAB-MS $m / z$ Calcd for $\mathrm{C}_{15} \mathrm{H}_{26} \mathrm{NO}_{3} \mathrm{Si}$ : 296.1682, Found: 296.1682 .

(7S)-7-[[(1,1-Dimethylethyl)dimethylsilyl]oxy]-6,7-dihydro-7-methyl5-oxo-5H-cyclopenta[c]pyridine-4-carboxylic Acid Methyl Ester (14a) A solution of 13a $(177 \mathrm{mg}, 0.50 \mathrm{mmol})$ in $o$-DCB $(10 \mathrm{ml})$ was heated at $150^{\circ} \mathrm{C}$ in an atmosphere of $\mathrm{Ar}$ for $48 \mathrm{~h}$. The reaction mixture was then concentrated in vacuo to leave a dark brown oil, which was subjected to flash chromatography [hexane-AcOEt $(3: 1)$ ]. Earlier fractions furnished 14a $(61.8 \mathrm{mg}, 37 \%)$ as a slightly yellow oil, $[\alpha]_{\mathrm{D}}^{22}+105.7^{\circ}\left(c=0.50, \mathrm{CHCl}_{3}\right)$; FAB-MS $m / z: 336\left(\mathrm{M}+\mathrm{H}^{+}\right)$; IR $v_{\max }^{\text {film: }} 1730 \mathrm{~cm}^{-1}$ (br, ester CO and CO); ${ }^{1} \mathrm{H}-$ NMR $\left(\mathrm{CDCl}_{3}\right) \delta: 0.00$ and 0.11 (3H each, s, $\left.\mathrm{SiMe}_{2}\right), 0.86(9 \mathrm{H}, \mathrm{s}$, tert-Bu), $1.71(3 \mathrm{H}, \mathrm{s}, \mathrm{CMe}), 2.91$ and $2.99\left[1 \mathrm{H}\right.$ each, d, $\left.J=18 \mathrm{~Hz}, \mathrm{C}(6) \mathrm{H}_{2}\right], 3.99(3 \mathrm{H}$, $\left.\mathrm{s}, \mathrm{CO}_{2} \mathrm{Me}\right), 8.98[1 \mathrm{H}, \mathrm{s}, \mathrm{C}(1) \mathrm{H}], 9.17[1 \mathrm{H}, \mathrm{s}, \mathrm{C}(3) \mathrm{H}] ; \mathrm{HR}-\mathrm{FAB}-\mathrm{MS} \mathrm{m} / \mathrm{z}$ Calcd for $\mathrm{C}_{17} \mathrm{H}_{26} \mathrm{NO}_{4} \mathrm{Si}$ : 336.1631, Found: 336.1614.

Later fractions in the above chromatography gave the starting oxazoleolefin 13a (41.4 $\mathrm{mg}, 23 \%$ recovery).

(7S)-7-I[(1,1-Dimethylethyl)dimethylsilyl]oxy]-6,7-dihydro-7-methyl$\mathbf{5 H}$-cyclopenta[c]pyridin-5-one (14b) A solution of 13b (292 mg, $0.99 \mathrm{mmol})$ in $o$-DCB $(20 \mathrm{ml})$ was heated at $150{ }^{\circ} \mathrm{C}$ in an atmosphere of $\mathrm{Ar}$ for $9 \mathrm{~h}$. The reaction mixture was then concentrated in vacuo to leave a dark brown oil, which was purified by flash chromatography [hexane-AcOEt $(4: 1)$ ] to afford $\mathbf{1 4 b}(62.8 \mathrm{mg}, 23 \%)$ as a slightly yellow solid, $\mathrm{mp} 58$ $59^{\circ} \mathrm{C} ;[\alpha]_{\mathrm{D}}^{28}+84.8^{\circ}\left(c=0.50, \mathrm{CHCl}_{3}\right) ;$ FAB-MS $m / z: 278\left(\mathrm{M}+\mathrm{H}^{+}\right)$; IR $v_{\max }^{\text {Nujol: }} 1728 \mathrm{~cm}^{-1}(\mathrm{CO}) ;{ }^{1} \mathrm{H}-\mathrm{NMR}\left(\mathrm{CDCl}_{3}\right) \delta:-0.05$ and $0.04(3 \mathrm{H}$ each, $\mathrm{s}$, $\left.\mathrm{SiMe}_{2}\right), 0.86(9 \mathrm{H}, \mathrm{s}$, tert-Bu), $1.73(3 \mathrm{H}, \mathrm{s}, \mathrm{CMe}), 2.86$ and 2.94 [1H each, d, $\left.J=18.5 \mathrm{~Hz}, \mathrm{C}(6) \mathrm{H}_{2}\right], 7.52[1 \mathrm{H}, \mathrm{dd}, J=5,1.5 \mathrm{~Hz}, \mathrm{C}(4) \mathrm{H}], 8.78[1 \mathrm{H}, \mathrm{d}$, $J=5 \mathrm{~Hz}, \mathrm{C}(3) \mathrm{H}], 9.08[1 \mathrm{H}, \mathrm{d}, J=1.5 \mathrm{~Hz}, \mathrm{C}(1) \mathrm{H}]$; HR-FAB-MS $m / z$ Calcd for $\mathrm{C}_{15} \mathrm{H}_{24} \mathrm{NO}_{2} \mathrm{Si}: 278.1576$, Found: 278.1573.

5-(5-Oxazolyl)-1,4-hexadien-3-one (18) A stirred mixture of 13b $(70.4 \mathrm{mg}, 0.24 \mathrm{mmol})$ and $\mathrm{Cu}(\mathrm{OTf})_{2}(1.7 \mathrm{mg}, 2 \mathrm{~mol} \%)$ in $o$-DCB $(4.8 \mathrm{ml})$ was heated at $180^{\circ} \mathrm{C}$ in an atmosphere of Ar for $40 \mathrm{~min}$. The reaction mixture was concentrated in vacuo, and the residual brown oil was purified by flash chromatography [hexane-AcOEt $(5: 2)$ ] to give $\mathbf{1 8}(14.8 \mathrm{mg}, 38 \%)$ as a pale yellow solid, $\mathrm{mp} 35-36^{\circ} \mathrm{C}$; EI-MS $\mathrm{m} / \mathrm{z}: 163\left(\mathrm{M}^{+}\right)$; IR $v_{\max }^{\text {Nujol: }}$ : $1665 \mathrm{~cm}^{-1}(\mathrm{CO}) ;{ }^{1} \mathrm{H}-\mathrm{NMR}\left(\mathrm{CDCl}_{3}\right) \delta: 2.47(3 \mathrm{H}, \mathrm{s}, \mathrm{Me}), 5.85(1 \mathrm{H}, \mathrm{d}$, $J=10.5 \mathrm{~Hz})$ and $6.31(1 \mathrm{H}, \mathrm{d}, J=17 \mathrm{~Hz})\left[\mathrm{C}(1) \mathrm{H}_{2}\right], 6.52[1 \mathrm{H}, \mathrm{dd}, J=17,10.5$ $\mathrm{Hz}, \mathrm{C}(2) \mathrm{H}], 6.96[1 \mathrm{H}, \mathrm{s}, \mathrm{C}(4) \mathrm{H}], 7.37\left[1 \mathrm{H}, \mathrm{s}, \mathrm{C}\left(4^{\prime}\right) \mathrm{H}\right], 7.93\left[1 \mathrm{H}, \mathrm{s}, \mathrm{C}\left(2^{\prime}\right)-\right.$ $\mathrm{H}]{ }^{48)} \mathrm{HR}-\mathrm{EI}-\mathrm{MS} \mathrm{m} / z$ Calcd for $\mathrm{C}_{9} \mathrm{H}_{9} \mathrm{NO}_{2}: 163.0633$, Found: 163.0633 .

(5R,7S)-7-[[(1,1-Dimethylethyl)dimethylsilyl]oxy]-6,7-dihydro-5-hydroxy-7-methyl-5H-cyclopenta[c]pyridine-4-carboxylic Acid Methyl Ester (15a) A stirred solution of 14a $(50.3 \mathrm{mg}, 0.15 \mathrm{mmol})$ in $\mathrm{MeOH}$ $(1.5 \mathrm{ml})$ was cooled to $0^{\circ} \mathrm{C}$, and $\mathrm{NaBH}_{4}(5.7 \mathrm{mg}, 0.15 \mathrm{mmol})$ was added. After the mixture had been stirred at $0^{\circ} \mathrm{C}$ for $30 \mathrm{~min}$, acetone $(0.1 \mathrm{ml})$ was added. The resulting mixture was concentrated in vacuo, and the residual oil was partitioned between $\mathrm{CHCl}_{3}$ and $\mathrm{H}_{2} \mathrm{O}$. The $\mathrm{CHCl}_{3}$ extracts were washed with saturated aqueous $\mathrm{NaCl}$, dried, and concentrated to leave a colorless oil, which was then subjected to flash chromatography [hexane-AcOEt $(3: 1)$ ]. Earlier fractions provided 15a $(38.0 \mathrm{mg}, 75 \%)$ as a colorless oil, $[\alpha]_{\mathrm{D}}^{24}-4.0^{\circ}$ $\left(c=0.94, \mathrm{CHCl}_{3}\right)$; FAB-MS $m / z: 338\left(\mathrm{M}+\mathrm{H}^{+}\right)$; IR $v_{\max }^{\text {film }} \mathrm{cm}^{-1}: 3480(\mathrm{OH})$, 1708 (ester $\mathrm{CO}$ ); ${ }^{1} \mathrm{H}-\mathrm{NMR}\left(\mathrm{CDCl}_{3}\right) \delta: 0.04$ and 0.14 (3H each, s, $\mathrm{SiMe}_{2}$ ), $0.89(9 \mathrm{H}, \mathrm{s}$, tert-Bu $), 1.48(3 \mathrm{H}, \mathrm{s}, \mathrm{CMe}), 2.33(1 \mathrm{H}, \mathrm{dd}, J=12.5,8 \mathrm{~Hz})$ and $2.76(1 \mathrm{H}, \mathrm{dd}, J=12.5,7.5 \mathrm{~Hz})\left[\mathrm{C}(6) \mathrm{H}_{2}\right], 4.01\left(3 \mathrm{H}, \mathrm{s}, \mathrm{CO}_{2} \mathrm{Me}\right), 5.0(1 \mathrm{H}, \mathrm{br}$, $\mathrm{OH}), 5.39[1 \mathrm{H}, \mathrm{dd}, J=8,7.5 \mathrm{~Hz}, \mathrm{C}(5) \mathrm{H}], 8.79[1 \mathrm{H}, \mathrm{s}, \mathrm{C}(1) \mathrm{H}], 9.15[1 \mathrm{H}, \mathrm{s}$, $\mathrm{C}(3) \mathrm{H}]$; HR-FAB-MS $m / z$ Calcd for $\mathrm{C}_{17} \mathrm{H}_{28} \mathrm{NO}_{4} \mathrm{Si}$ : 338.1788, Found: 338.1791 .

Later fractions in the above chromatography afforded $\mathrm{C}(5)$-epimer $(5.2 \mathrm{mg}, 10 \%)$ of $15 \mathrm{a}$ as a colorless solid, $\mathrm{mp} 69-72^{\circ} \mathrm{C} ;[\alpha]_{\mathrm{D}}^{24}+8.8^{\circ}(c=$ $\left.0.26, \mathrm{CHCl}_{3}\right)$; FAB-MS $m / z: 338\left(\mathrm{M}+\mathrm{H}^{+}\right)$; IR $v_{\max }^{\text {Nujol }} \mathrm{cm}^{-1}: 3140(\mathrm{OH}), 1722$ (ester $\mathrm{CO}) ;{ }^{1} \mathrm{H}-\mathrm{NMR}\left(\mathrm{CDCl}_{3}\right) \delta$ : -0.03 and 0.01 (3H each, s, $\left.\mathrm{SiMe}_{2}\right), 0.81$ $(9 \mathrm{H}, \mathrm{s}$, tert-Bu), $1.73(3 \mathrm{H}, \mathrm{s}, \mathrm{CMe}), 2.22(1 \mathrm{H}, \mathrm{dd}, J=13.5,4.5 \mathrm{~Hz})$ and 2.64 $(1 \mathrm{H}, \mathrm{dd}, J=13.5,7.5 \mathrm{~Hz})\left[\mathrm{C}(6) \mathrm{H}_{2}\right], 4.01\left(3 \mathrm{H}, \mathrm{s}, \mathrm{CO}_{2} \mathrm{Me}\right), 4.37(1 \mathrm{H}, \mathrm{br}, \mathrm{OH})$, $5.61[1 \mathrm{H}, \mathrm{m}, \mathrm{C}(5) \mathrm{H}], 8.76[1 \mathrm{H}, \mathrm{s}, \mathrm{C}(1) \mathrm{H}], 9.13$ [1H, s, C(3)H]; HR-FAB-MS $m / z$ Calcd for $\mathrm{C}_{17} \mathrm{H}_{28} \mathrm{NO}_{4} \mathrm{Si}$ : 338.1788, Found: 338.1789.

$(5 R, 7 S)$-7-[I(1,1-Dimethylethyl)dimethylsilyl]oxy]-6,7-dihydro-7methyl-5H-cyclopentalclpyridin-5-ol (15b) A solution of $14 \mathrm{~b}(62.1 \mathrm{mg}$, $0.22 \mathrm{mmol})$ in EtOH $(1.5 \mathrm{ml})$ was treated with $\mathrm{NaBH}_{4}(12.5 \mathrm{mg}, 0.33 \mathrm{mmol})$ at $0{ }^{\circ} \mathrm{C}$ for $30 \mathrm{~min}$. The reaction mixture was worked up as described above for 15a, and purification of a crude oil by flash chromatography [AcOEthexane $(2: 1)$ ] provided $15 \mathrm{~b}(52.8 \mathrm{mg}, 84 \%)$ as a pale yellow solid, $\mathrm{mp}$ $104-107^{\circ} \mathrm{C} ;[\alpha]_{\mathrm{D}}^{24}+31.0^{\circ}\left(c=1.03, \mathrm{CHCl}_{3}\right)$; FAB-MS $m / z: 280\left(\mathrm{M}+\mathrm{H}^{+}\right)$; IR $v_{\max }^{\text {Nujol }}: 3140 \mathrm{~cm}^{-1}(\mathrm{OH}) ;{ }^{1} \mathrm{H}-\mathrm{NMR}\left(\mathrm{CDCl}_{3}\right) \delta: 0.05$ and 0.08 (3H each, $\mathrm{s}$, $\left.\mathrm{SiMe}_{2}\right), 0.86(9 \mathrm{H}, \mathrm{s}$, tert $-\mathrm{Bu}), 1.54(3 \mathrm{H}, \mathrm{s}, \mathrm{CMe}), 2.20$ and $2.62[1 \mathrm{H}$ each, dd, $\left.J=12.5,6.5 \mathrm{~Hz}, \mathrm{C}(6) \mathrm{H}_{2}\right], 2.6(1 \mathrm{H}, \mathrm{br}, \mathrm{OH}), 5.05[1 \mathrm{H}, \mathrm{dd}, J=6.5,6.5 \mathrm{~Hz}$, $\mathrm{C}(5) \mathrm{H}], 7.37[1 \mathrm{H}, \mathrm{d}, J=5 \mathrm{~Hz}, \mathrm{C}(4) \mathrm{H}], 8.55[1 \mathrm{H}, \mathrm{d}, J=5 \mathrm{~Hz}, \mathrm{C}(3) \mathrm{H}], 8.61$ [1H, s, C(1)H]; HR-FAB-MS $m / z$ Calcd for $\mathrm{C}_{15} \mathrm{H}_{26} \mathrm{NO}_{2} \mathrm{Si}: 280.1733$, Found: 280.1732 .

(5R,7S)-6,7-Dihydro-5,7-dihydroxy-7-methyl-5H-cyclopenta[c]pyridine-4-carboxylic Acid Methyl Ester [(-)-Plectrodorine] [(-)-1] A $1.0 \mathrm{M}$ solution $(0.26 \mathrm{ml}, 0.26 \mathrm{mmol})$ of tetrabutylammonium fluoride in THF was added to a stirred solution of $15 \mathrm{a}(29.4 \mathrm{mg}, 0.087 \mathrm{mmol})$ in THF $(1.0 \mathrm{ml})$. After having been stirred at room temperature for $2 \mathrm{~h}$, the reaction mixture was concentrated in vacuo to leave a yellow oil. Purification by flash chromatography $\left[\mathrm{CHCl}_{3}-\mathrm{MeOH}(15: 1)\right]$ furnished $(-)-\mathbf{1}(14.2 \mathrm{mg}, 73 \%)$ as a colorless oil, $[\alpha]_{\mathrm{D}}^{24}-78.4^{\circ}(c=0.40, \mathrm{MeOH})$; HR-EI-MS $m / z$ Calcd for $\mathrm{C}_{11} \mathrm{H}_{13} \mathrm{NO}_{4}$ : 223.0844, Found: 223.0847. The UV (MeOH), ${ }^{1} \mathrm{H}-\mathrm{NMR}$ $\left(\mathrm{CDCl}_{3}\right)$, and mass spectral data of this sample were in agreement with those reported for natural plectrodorine. ${ }^{24)}$

(5R,7S)-6,7-Dihydro-7-methyl-5H-cyclopenta[c]pyridine-5,7-diol [(+)Oxerine] [(+)-3] Deprotection of 15b $(52.8 \mathrm{mg}, 0.19 \mathrm{mmol})$ with tetrabutylammonium fluoride and work-up of the reaction mixture were carried out as described above for $(-)-\mathbf{1}$. Purification of a crude oil by flash chromatography $\left[\mathrm{CHCl}_{3}-\mathrm{MeOH}(10: 1)\right]$ gave $(+)-3(28.4 \mathrm{mg}, 91 \%)$ as a colorless solid, mp $120-122^{\circ} \mathrm{C} ;[\alpha]_{\mathrm{D}}^{23}+10.6^{\circ}(c=0.21, \mathrm{MeOH}) ; \mathrm{CD} \lambda_{\mathrm{ext}}^{\mathrm{MeOH}} \mathrm{nm}$ $(\Delta \varepsilon): 267(+2.54), 264(+2.00), 261(+2.15), 244(-1.04), 231(-0.39)$, $214(-2.17)$; HR-EI-MS $m / z$ Calcd for $\mathrm{C}_{9} \mathrm{H}_{11} \mathrm{NO}_{2}: 165.0790$, Found: 165.0788. The UV $(\mathrm{MeOH}),{ }^{1} \mathrm{H}-\mathrm{NMR}\left(\mathrm{CD}_{3} \mathrm{OD}\right)$, and mass spectral data of this sample were virtually identical with those of natural oxerine. ${ }^{25)}$

Acknowledgement We are grateful to Professor M. Koch (Université René Descartes-Paris V) for his invaluable help in making a comparison between the natural and synthetic alkaloids.

\section{References and Notes}

1) For a recent review on the oxazole Diels-Alder reactions, see Levin J. I., Laakso L. M., "The Chemistry of Heterocyclic Compounds," Vol. 60, Part A, Chap. 3, ed. by Palmer D. C., John Wiley \& Sons, Inc., Hoboken, 2003.

2) Kondrat'eva G. Y., Khim. Nauka i Prom., 2, 666-667 (1957) [Chem. Abstr., 52, 6345a (1958)].

3) Kondrat'eva G. Y., Izv. Akad. Nauk SSSR., Otdel. Khim. Nauk, 1959, 484-490 (1959) [Chem. Abstr., 53, 21940d (1959)].

4) Levin J. I., Weinreb S. M., J. Am. Chem. Soc., 105, 1397-1398 (1983).

5) Levin J. I., Weinreb S. M., J. Org. Chem., 49, 4325-4332 (1984).

6) Ohba M., Kubo H., Fujii T., Ishibashi H., Sargent M. V., Arbain D., Tetrahedron Lett., 38, 6697-6700 (1997).

7) Ohba M., Kubo H., Ishibashi H., Tetrahedron, 56, 7751-7761 (2000).

8) Ohba M., Natsutani I., Sakuma T., Tetrahedron Lett., 45, 6471—6474 
(2004).

9) Ohba M., Natsutani I., Heterocycles, 63, 2845-2850 (2004).

10) For other intramolecular oxazole-olefin Diels-Alder reactions, see refs. $11-19$

11) Shimada S., Tojo T., Chem. Pharm. Bull., 31, 4247-4258 (1983).

12) Levin J. I., Tetrahedron Lett., 30, 2355-2358 (1989).

13) Subramanyam C., Noguchi M., Weinreb S. M., J. Org. Chem., 54, 5580-5585 (1989).

14) Jung M. E., Dansereau S. M. K., Heterocycles, 39, 767-778 (1994).

15) Padwa A., Brodney M. A., Liu B., Satake K., Wu T., J. Org. Chem., 64, 3595-3607 (1999).

16) Sun X., Janvier P., Zhao G., Bienaymé H., Zhu J., Org. Lett., 3, 877880 (2001).

17) Janvier P., Sun X., Bienaymé H., Zhu J., J. Am. Chem. Soc., 124, $2560-2567$ (2002).

18) González-Zamora E., Fayol A., Bois-Choussy M., Chiaroni A., Zhu J., Chem. Commun., 2001, 1684-1685 (2001).

19) Gámez-Montaño R., González-Zamora E., Potier P., Zhu J., Tetrahedron, 58, 6351-6358 (2002).

20) For reviews on the monoterpene alkaloids, see refs. $21-23$

21) Cordell G. A., "The Alkaloids," Vol. 16, Chap. 8, ed. by Manske R. H. F., Academic Press, New York, 1977.

22) Strunz G. M., Findlay J. A., "The Alkaloids," Vol. 26, Chap. 3, ed. by Brossi A., Academic Press, Orlando, 1985.

23) Cordell G. A., "The Alkaloids," Vol. 52, Chap. 5, ed. by Cordell G. A., Academic Press, San Diego, 1999.

24) Gournelis D., Skaltsounis A.-L., Tillequin F., Koch M., Pusset J., Labarre S., J. Nat. Prod., 52, 306-316 (1989).

25) Benkrief R., Skaltsounis A.-L., Tillequin F., Koch M., Pusset J., Planta Med., 57, 79-80 (1991).

26) Weinges K., Zourari M., Smuda H., Rodewald H., Nixdorf M., Irngartinger H., Liebigs Ann. Chem., 1985, 1063-1081 (1985).

27) Aoyagi Y., Inariyama T., Arai Y., Tsuchida S., Matuda Y., Kobayashi H., Ohta A., Kurihara T., Fujihira S., Tetrahedron, 50, 13575-13582 (1994).
28) Jones K., Fiumana A., Tetrahedron Lett., 37, 8049-8052 (1996).

29) Jones K., Fiumana A., Escudero-Hernandez M. L., Tetrahedron, 56, $397-406$ (2000).

30) Zhao J., Yang X., Jia X., Luo S., Zhai H., Tetrahedron, 59, 9379 $9382(2003)$.

31) Ohba M., Izuta R., Shimizu E., Tetrahedron Lett., 41, 10251-10255 (2000).

32) Jacobi P. A., Walker D. G., Odeh I. M. A., J. Org. Chem., 46, 20652069 (1981).

33) Jacobi P. A., Craig T. A., Walker D. G., Arrick B. A., Frechette R. F., J. Am. Chem. Soc., 106, 5585-5594 (1984).

34) Seebach D., Naef R., Calderari G., Tetrahedron, 40, 1313-1324 (1984).

35) The absolute configuration of 7 was defined by a chemical correlation with $(S)-(+)$-citramalic acid. ${ }^{34)}$

36) Davis F. A., Reddy G. V., Chen B.-C., Kumar A., Haque M. S., J. Org. Chem., 60, 6148-6153 (1995).

37) Mancuso A. J., Swern D., Synthesis, 1981, 165-185 (1981).

38) Oda H., Kobayashi T., Kosugi M., Migita T., Tetrahedron, 51, 695702 (1995).

39) Takai K., Kimura K., Kuroda T., Hiyama T., Nozaki H., Tetrahedron Lett., 24, 5281-5284 (1983).

40) Takai K., Tagashira M., Kuroda T., Oshima K., Utimoto K., Nozaki H., J. Am. Chem. Soc., 108, 6048-6050 (1986).

41) Jin H., Uenishi J., Christ W. J., Kishi Y., J. Am. Chem. Soc., 108, 5644-5646 (1986).

42) Dess D. B., Martin J. C., J. Org. Chem., 48, 4155-4156 (1983).

43) Dess D. B., Martin J. C., J. Am. Chem. Soc., 113, 7277-7287 (1991).

44) Ireland R. E., Liu L., J. Org. Chem., 58, 2899 (1993).

45) Ohba M., Izuta R., Heterocycles, 55, 823-826 (2001).

46) Although $\mathbf{1 8}$ was obtained as a single isomer, the geometry of the newly generated double bond was not determined.

47) Still W. C., Kahn M., Mitra A., J. Org. Chem., 43, 2923-2925 (1978).

48) For convenience, each position of the oxazole ring is indicated by a primed number. 